\title{
PENGARUH LIKUIDITAS DAN LEVERAGE TERHADAP NILAI PERUSAHAAN DENGAN PROFITABILITAS SEBAGAI VARIABEL INTERVENING
}

\author{
Reni Febriani \\ Universitas Banten Jaya \\ Serang, Indonesia \\ renifebriani@unbaja.ac.id
}

\begin{abstract}
The value of the company was important because of the high valuation of the community on the company's shares, which would be followed by the high level of prosperity of shareholders. This study aimed to determine the effect of proxied liquidity through Current Asset and leverage proxied through the Debt to Equity Ratio of firm value proxied through Price to Book Value with profitability proxied through Return on Asset as an intervening variable. The study population were 144 manufacturing companies listed on the Indonesia Stock Exchange for the period 2014-2018 with a total of 13 companies taken. The method of data analysis used path analysis by testing mediating variables using the sobel method. The results showed 1) Liquidity had a negative and significant effect on firm value. 2) Leverage had a negative and significant effect on firm value. 3) Liquidity did not affect profitability. 4) Leverage had a negative and significant effect on profitability. 5) Profitability has a positive effect on company value. 6) Profitability did not mediate the effect of liquidity and leverage on firm value.
\end{abstract}

\section{Keywords: Liquidity, Leverage, Profitability and Company Value}

\section{PENDAHULUAN}

Nilai perusahaan merupakan kondisi tertentu yang telah dicapai oleh suatu perusahaan sebagai gambaran dari kepercayaan masyarakat terhadap perusahaan setelah melalui suatu proses kegiatan selama beberapa tahun, yaitu sejak perusahaan tersebut didirikan sampai dengan saat ini (Noerirawan, 2012). Meningkatnya nilai perusahaan yang identik dengan tinggi harga saham menjadi sebuah prestasi yang menjadi keinginan para pemilik saham. Nilai perusahaan menjadi penting karena tingginya penilaian masyarakat pada saham perusahaan akan diikuti tingginya kemakuran pemegang saham.

Beberapa aspek finansial yang mempengaruhi nilai perusahaan yang diantaranya likuiditas. Menurut Harahap (2014), likuiditas menggambarkan kemampuan perusahaan untuk menyelesaikan kewajiban jangka pendeknya. Sedangkan menurut Kasmir (2015) likuiditas merupakan rasio yang digunakan untuk mengukur seberapa 
likuidnya suatu perusahaan. Likuiditas menunjukan sejauhmana aktiva lancar menutupi kewajiban-kewajiban lancar. Semakin besar perbandingan aktiva lancar dan kewajiban lancar maka semakin tinggi kemampuan perusahaan menutupi kewajiban jangka pendeknya.

Leverage termasuk faktor yang mempengaruhi nilai perusahaan. Dalam meningkatkan keuntungan, perusahaan memerlukan leverage yang menjadi kebijakan perusahaan tentang sejauhmana perusahaan menggunakaan pendanaan hutang. Teori trade off memprediksi hubungan positif antara struktur modal dengan nilai perusahaan dengan asumsi keuntungan pajak masih lebih besar dari biaya kepailitan dan biaya keagenen (Husnan, 2012). Semakin tinggi nilai perusahaan maka akan semakin meningkat pula tingkat hutang.

Penelitian ini menggunakan rasio profitabilitas yaitu untuk menilai kemampuan perusahaan dalam mencari keuntungan. Menurut Fahmi (2015) rasio profitabilitas melihat sejauhmana investasi yang telah ditanamkan mampu memberikan pengembalian keuntungan sesuai dengan yang diharapkan. Sedangkan menurut Harahap (2014) profitabilitas menggambarkan kemampuan untuk mendapatkan laba melalui semua kemampuan, dan sumber yang ada seperti kegiatan penjualan, kas, modal, jumlah karyawan, jumlah cabang dan sebagainya.

Sepanjang tahun 2014-2018 perusahaan manufaktur setiap tahunnya mengalami penurunan nilai perusahaan, hal ini dapat dilihat pada grafik 1.1 sebagai berikut :

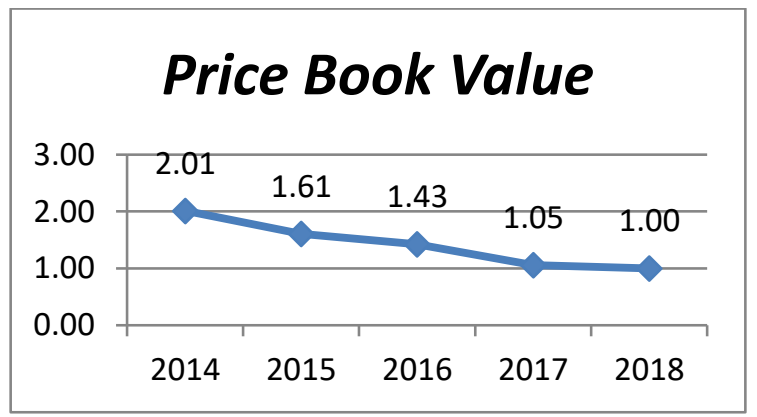

Sumber: Data ICMD diolah, 2019.

Dapat kita lihat dari grafik 1.1 di atas adanya penurunan yang signifikan yang terjadi pada nilai perusahaan (PBV) pada tahun 2014-2018. Pada periode 2014 ke 2015 mengalami penurunan sampai dengan $4.94 \%$ dari 2,01 menjadi 1,61 periode 2015 ke 2016 menurun sebesar $8,96 \%$ dari 1,61 menjadi 1,43 periode 2016 ke 2017 menurun sebesar 3,83\% dari 1,43 menjadi 1,05 dan turun kembali pada periode 2017 ke 2018 menurun sampai $19,31 \%$ dari 1,05 menjadi 1,00 .

Bersamaan dengan penurunan pada rasio nilai perusahaan, hasil pengamatan pada rasio likuiditas dan leverage pada perusahaan manufaktur di periode yang 
sama menunjukan pola pertumbuhan yang fluktuasi. Hal ini sebagaimana dapat dilihat pada grafik :

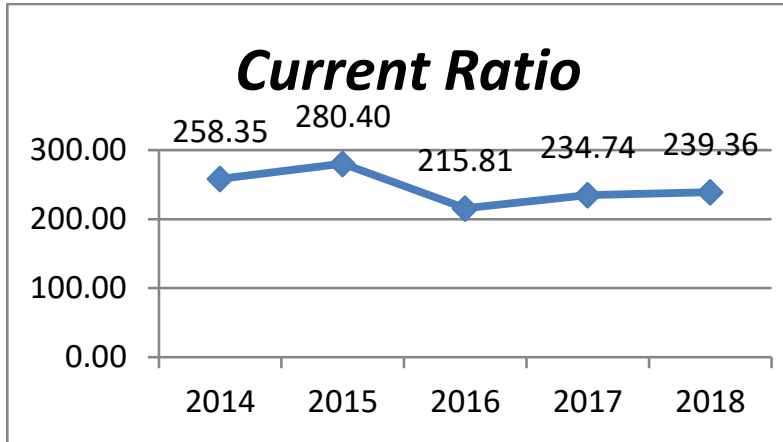

Sumber: Data ICMD diolah, 2019.

Likuiditas perusahaan salah satunya dapat ditunjukan oleh Current Ratio (CR). Perusahaan yang mempunyai CR yang tinggi berarti mempunyai tingkat likuiditas yang tinggi yang juga mengindikasikan kesempatan perusahaan dalam mengembangkan perusahaan sehingga dapat menaikan nilai perusahaan. Namun demikian Grafik 1.2 menunjukan bahwa rata-rata perusahaan manufaktur mengalami pertumbuhan CR yang fluktuatif bahkan cenderung menurun. Dari CR sebesar 258,35\% di tahun 2014, perusahaan manufaktur terlihat mampu meningkatkan likuiditasnya menjadi $280,40 \%$ di tahun 2015. Namun demikian nilai ini terlihat menurun hingga mencapai angka $215,81 \%$ di tahun 2016. Meskipun terus menunjukan kenaikan pada tahuntahun berikutnya, namun nilai likuiditas dari perusahaan manufaktur terlihat tidak mampu kembali pada angka semula.

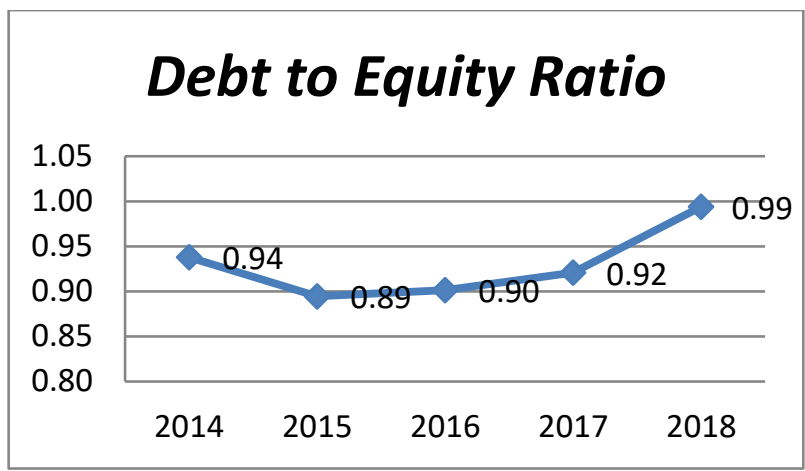

Sumber: Data ICMD diolah, 2019.

Perubahan leverage menghasilkan perubahan dalam tingkat pengembalian dan risiko, dimana penggunaan dana nantinya dimaksudkan untuk meningkatkan keuntungan potensial bagi para pemegang saham. Berbeda dengan pola pertumbuhan nilai perusahaan dan $\mathrm{CR}$, terlihat leverage perusahaan manufaktur yang ditunjukan oleh Debt to Equity Ratio (DER) mengalami pola pertumbuhan yang cenderung meningkat. Dari angka 0,94 di tahun 2014, rata-rata perusahaan manufaktur cenderung terus meningkatkan penggunaan dana eksternalnya hingga mencapai angka 0,99 di tahun 2018. Meskipun sempat mengalami penurunan di tahun 2015 dengan rata-rata DER sebesar 0,89 namun peningkatan yang terjadi mengindikasikan kondisi bahwa sebagian besar perusahaan 
manufaktur sedang melakukan ekspansi bisnis yang besar atau sebaliknya yaitu mengalami kekurangan pada sisi dana internal perusahaan sehingga harus menggunakan utang yang besar untuk membiayai kebutuhan perusahaan.

Penurunan nilai perusahaan pada perusahaan manufaktur tersebut dapat di sebabkan oleh beberapa faktor. Menurut penelitian yang dilakukan oleh Putri dan Ukhriyawati (2016) membuktikan bahwa likuiditas tidak berpengaruh secara signifikan terhadap nilai perusahaan. Hasil berbeda dengan penelitian yang dilakukan oleh Mery (2017), membuktikan bahwa likuiditas berpengaruh positif signifikan terhadap nilai perusahaan. Sedangkan penelitian di atas bertentangan dengan Wijaya and Purnawati (2014) yang menyatakan bahwa likuiditas berpengaruh negatif dan signifikan terhadap nilai perusahaan.

Ramadhani et al., (2016) menyatakan bahwa leverage terhadap nilai perusahaan berpengaruh positif signifikan berbeda dengan penelitian Hasibuan dan Ar (2015) menunjukan bahwa leverage berpengaruh negative signifikan terhadap nilai perusahaan. Sedangkan penelitian Sambora (2014) membuktikan bahwa leverage terhadap nilai perusahaan tidak berpengaruh signifikan.
Berdasarkan research gap tersebut memunculkan masalah penelitian yaitu mengapa terjadi gap dalam hubungan likuiditas dan laverage terhadap nilai perusahaan. Beberapa peneliti sebelumnya memberi petunjuk profitabilitas dapat digunakan seabagai variabel mediasi untuk mengatasi gap tersebut. Putri, Zahroh and Endang (2016) meyatakan bahwa hubungan likuiditas berpengaruh positif terhadap nilai perusahaan melalui profitabilitas. Sedangkan Astutik (2017), menyatakan hubungan leverage berpengaruh positif terhadap nilai perusahaan melalui profitabilitas..

Alasan memasukan profitabilitas sebagai variabel intervening dikarenakan profitabilitas bisa menjadi perantara (mediasi) dar hubungan variabel penjelas yang dalam hal ini adalah likuiditas dan laverage ke variabel pengaruh yaitu nilai perusahaan, sehingga menjadi sebab perubahaan. Dengan meningkatnya profitabilitas maka semakin likuid suatu perusahaan dalam membayar atau memenuhi kewajiban yang jatuh tempo sehingga mengurangi resiko kebangkrutan, dan semakin besar penggunaan hutang yang menguntungkan, maka menghasilkan pendapatan lebih besar dari beban bunga yang timbul dari penggunaan hutang tersebut. Sesuai dengan signaling theory 
perusahaan dengan tingkat likuiditas yang naik atau tinggi akan mendaptakan kepercayaan investor karna menunjukan bahwa perusahaan memiliki stabilitas yang tinggi. Menurut teori sinyal peningkatan profitabilitas menyebabkan kenaikan prmintaan saham oleh investor, sehingga nilai perusahaan meningkat.

Sedangkan tingginya leverage dapat meningkatkan nilai perusahaan apabila pengunaan hutang pada tingkat tertentu dapat memberikan manfaat yang pada akhirnya akan meningkatkan produksi sehingga dapat menghasilkan laba dan dengan profitabilitas yang tinggi akan meningkatkan nilai perusahaan. Hal ini sesuai dengan trade off theory yang menjelaskan bahwa peningkatan profitabilitas menyebabkan kenaikan permintaan saham dan memberikan sinyal positif sehingga nilai perusaan meningkat.

\section{Rumusan Masalah}

Berdasarkan rumusan penelitian tersebut maka dapat disimpulkan beberapa pertanyaan penelitian ini sebagai berikut:

1. Apakah likuiditas berpengaruh terhadap nilai perusahaan pada perusahaan manufaktur yang terdaftar di Bursa Efek Indonesia periode tahun 2014-2018?
2. Apakah leverage berpengaruh terhadap nilai perusahaan pada perusahaan manufaktur yang terdaftar di Bursa Efek Indonesia periode tahun 2014$2018 ?$

3. Apakah likuiditas berpengaruh terhadap profitabilitas pada perusahaan manufaktur yang terdaftar di Bursa Efek Indonesia periode tahun 2014$2018 ?$

4. Apakah leverage berpengaruh terhadap profitabilitas pada perusahaan manufaktur yang terdaftar di Bursa Efek Indonesia periode tahun 2014$2018 ?$

5. Apakah profitabilitas berpengaruh terhadap nilai perusahaan pada perusahaan manufaktur yang terdaftar di Bursa Efek Indonesia periode tahun 2014-2018?

\section{Kajian Pustaka}

\section{Signaling Theory}

Menurut Fahmi (2015) signaling theory merupakan teori yang membahas tentang naik turunnya harga di pasar, sehingga akan memberikan pengaruh kepada keputusan investor. Sinyal ini berupa informasi mengenai apa yang sudah dilakukan oleh manajemen untuk merealisasikan keinginan pemilik. Signalling merupakan kegiatan pendanaan 
Universitas Banten Jaya

manajer yang dipercaya dapat merefleksikan nilai dari perusahaan nilai dari saham perusahaan.

Rasio likuiditas yang akan memberikan informasi penting bagi pertumbuhan dan perkembangan perusahaan dalam jangka pendek. Penelitian ini mengindikasikan bahwa semakin tinggi leverage maka semakin besar kepercayaan dari pihak luar untuk memperoleh pendanaan, hal ini sangat memungkinkan dalam upaya peningkatan kinerja keuangan perusahaan. Sedangkan berdasarkan teori signaling apabila profitabilitas perusahaan mengalami peningkatan respon positif dari investor maka menyebabkan kenaikan nilai perusahaan.

\section{Trade off Theory}

Model trade off mengasumsikan bahwa struktur modal perusahaan merupakan hasil trade off dari keuntungan pajak dengan menggunakan hutang dengan biaya yang akan timbul sebagai akibat penggunaan hutang tersebut. Esensi trade off theory dalam struktur modal adalah menyeimbangkan manfaat dan pengorbanan yang timbul sebagai akibat penggunaan hutang. Sejauh manfaat lebih besar, tambahan utang masih diperkenankan. Apabila pengorbanan karena penggunaan hutang sudah lebih besar, maka tambahan hutang sudah tidak diperbolehkan.

Tingkat hutang yang optimal tercapai ketika penghematan pajak (tax shields) mencapai jumlah yang maksimal terhadap biaya kesulitan keuangan (costsof financial distress). Trade off theory mempunyai implikasi bahwa manajer akan berpikir dalam kerangka trade off antara penghematan pajak dan biaya kesulitan keuangan dalam penentuan struktur modal. Perusahaan-perusahaan dengan tingkat profitabilitas yang tinggi tentu akan berusaha mengurangi pajaknya dengan cara meningkatkan rasio hutangnya, sehingga tambahan hutang tersebut akan mengurangi pajak.

Teori ini menjelaskan ide bahwa berapa banyak utang perusahaan dan berapa banyak ekuitas perusahaan sehingga terjadinya keseimbangan antara biaya dan keuntungan. Teori trade off memprediksi hubungan positif antara struktur modal dengan nilai perusahaan dengan asumsi keuntungan pajak masih lebih besar dari biaya kepailitan dan biaya keagenan (Husnan, 2012). Pada intinya teori trade off menunjukkan bahwa nilai perusahaan dengan hutang akan semakin meningkat dengan meningkatnya pula tingkat hutang. Penggunaan hutang akan meningkatkan nilai perusahaan tetapi 
hanya pada sampai titik tertentu. Setelah titik tersebut, penggunaan hutang justru menurunkan nilai perusahaan.

Kombinasi optimal dari struktur modal meminimalkan biaya modal, yang kemudian memaksimalkan kinerja perusahaan. Perusahaan leverage yang tinggi diharapkan dapat meningkatkan kinerja mereka dengan menyederhanakan konflik tentang arus kas bebas di antara pemegang saham dan manajer (Kausar, Nazir dan Butt, 2014). Oleh karena itu, perusahaan menggunakan proporsi utang yang tinggi dalam struktur modal dan kinerja tinggi dengan manfaat perisai pajak.

\section{Nilai Perusahaan}

Brigham dan Houston (2015) yang dialih bahasakan oleh yulianto, nilai perusahaan didefinisikan sebagai berikut: "tujuan utama dari keputusan manajerial ialah dengan mempertimbangkan resiko dan waktu yang terkait dengan perkiraan laba per saham untuk memaksimalkan harga saham biasa perusahaan". Menjelaskan bahwa jika harga saham yang dimiliki perusahaan tinggi maka mencerminkan penilaian investor terhadap perusahaan karena perusahaan dianggap mampu memaksimalkan kekayaan pemegang saham.
Price to book value (PBV) adalah rasio yang menunjukan hasil perbandingan antara harga pasar per lembar saham dengan nilai buku per lembar saham. Rasio ini digunakan untuk mengukur tingkat harga saham apakah overvalued atau undervalued. Semakin rendah nilai pbv suatu saham maka saham tersebut di kategorikan undervalued, di mana sangat baik untuk investasi jangka panjang. Namun, rendahnya nilai PBV juga dapat mengindikasikan menurunnya kualitas dan kinerja fundamental emiten. Oleh sebab itu, nilai pbv juga harus dibandingkan dengan pbv saham emiten lainnya dalam industry yang sama. Apabila terlalu jauh berbeda maka sebaiknya perlu di analisis lebih lanjut Hery (2016). Adapun rumus yang digunakan untuk mengukur price to book value (PBV) adalah sebagai berikut Fahmi (2015) :

$$
P B V=\frac{\text { Market Price per Share }}{\text { Book Value per Share }}
$$

\section{Likuiditas}

Hery (2016), rasio likuiditas merupakan rasio yang menggambarkan kemampuan perusahaan dalam memenuhi kewajiban jangka pendeknya yang segera jatuh tempo. Jika perusahaan memiliki kemampuan untuk melunasi kewajiban jangka pendeknya pada saat jatoh tempo 
maka perusahahaan tersebut di katakana perusahaan yang likuid. Sebaliknya jika perusahaan tidak memiliki kemampuan untuk melunasi kewajiban jangka pendeknya pada saat jatuh tempo maka dapat di katakana perusahaan tersebut tidak likuid.

Current ratio (CR) atau rasio lancarmerupakan rasio yang digunakan untuk mengukur kemampuan perusahaan dalam memenuhi kewajiban jangka pendeknya yang segera jatoh tempo dengan menggunakan total asset lancar yang tersedia. Dengan kata lain rasio lancar ini menggambarkan seberapa jauh ketersediaan asset lancar yang di miliki perusahaan di bandingkan dengan total kewajiban lancar. Oleh sebab itu, rasio lancar dihitung sebagai hasil bagi antara total asset lancar dengan total kewajiban lancar. Rumus perhitungan current ratio adalah sebagai berikut:

$$
(C R)=\frac{\text { Aset Lancar }}{\text { Kewajiban Lancar }}
$$

\section{Leverage}

Menurut Harahap (2014), rasio leverage merupakan rasio yang mengukur seberapa jauh perusahaan dibiayai oleh kewajiban atau pihak luar dengan kemampuan perusahaan yang digambarkan oleh ekuitas. Sedangkan menurut Sartono
(2015) financial leverage menunjukan proporsi atas penggunaan utang untuk membiayai investasinya. Perusahaan yang tidak mempunyai leverage berarti menggunakan modal sendiri $100 \%$. Penggunaan utang itu sendiri bagi perusahaan mengandung tiga dimensi (1) pemberi kredit akan menitikberatkan pada besarnya jaminan atas kredit yang diberikan; (2) apabila perusahaan mendapatkan keuntungan yang lebih besar dari beban tetapnya maka pemilik perusahaan keuntungannya akan meningkat dan (3) dengan menggunakan utang maka pemilik memperoleh dana dan tidak kehilangan pengendalian perusahaan.

Debt to equity ratio (DER) atau rasio utang terhadap equitas, rasio ini merupakan rasio yang digunakan unutk mengukur perbandingan antara total utang dengan total equitas. Menunjukkan hubungan antara jumlah hutang yang diberikan oleh para kreditur dengan jumlah modal sendiri yang diberikan oleh pemilik perusahaan (Hery, 2016). Adapun rumus yang digunakan untuk mengukur debt to equity ratio (DER) adalah :

$$
D E R=\frac{\text { Total Hutang }}{\text { Modal Sendiri }}
$$




\section{Profitabilitas}

Menurut Kasmir (2015) rasio profitabilitas merupakan rasio untuk menilai kemampuan perusahaan dalam mencari keuntungan. Rasio ini juga memberikan ukuran tingkat efektivitas manajemen suatu perusahaan. Hal ini ditunjukan oleh laba yang dihasilkan dari penjualan dan pendapatan investasi. Intinya adalah penggunaan rasio ini menunjukkan efisiensi perusahaan.

ROA biasa juga disebut sebagai ROI (Return On Investment). Rasio ini melihat sejauh mana investasi yang telah ditanamkan mampu memberikan pengembalian keuntungan sesuai dengan yang diharapkan. Adapun rumus yang dapat digunakan adalah:

$$
\text { ROA }=\frac{\text { Earning After Tax }(\text { EAT })}{\text { Total Asset }}
$$

\section{Hipotesis}

\section{Pengaruh Likuiditas terhadap Nilai Perusahaan}

Tingginya likuiditas mampu menunjukan dana yang tersedia untuk pembayaran deviden, membiayai operasi perusahaan dan investasi sehingga persepsi investor pada perusahaan menunjukan sinyal yang baik pula. Hal ini di sebabkan perusahaan yang memiliki tingkat likuiditas yang tinggi mempunyai dana internal yang besar, sehinnga perusahaan menggunakan dana internalnya terlebih dahulu untuk kebutuhan investasinya sebelum menggunakan dana eksternalnya melalui hutang (Putra and Lestari, 2016).

Jika perusahaan masih memiliki kemampuan yang bagus dalam memenuhi kewajiban jangka pendeknya (periode satu tahun) dengan menggunakan aktiva lancar maka perusahaan dapat dikatakan likuid. Dengan demikian investor tidak perlu khawatir dalam menginvestasikan dananya, jika suatu saat terjadi hal yang tidak diinginkan.

Adelina (2014) dengan judul penelitiannya pengaruh rasio likuiditas, leverage dan profitabilitas terhadap Nilai Perusahaan Pada Industri Barang Konsumsi Yang Terdaftar di Bursa Efek Indonesia Tahun 2010-2012. Penelitian ini menggunakan metode analisa Statistik Deskriptif. Hasil penelitian menunjukkan bahwa terdapat pengaruh likuiditas (CR) terhadap nilai perusahaan.

Secara empiric lainnya relevan dengan penelitian Putra (2016) yang bertujuan untuk menguji pengaruh kebijakan dividen, likuiditas, profitabilitas dan ukuran perusahaan terhadap nilai perusahaan Jumlah sampel yang diambil adalah 20 perusahaan. Hasil penelitian menunjukkan bahwa likuiditas 
berpengaruh positif dan signifikan terhadapnilai perusahaan.

H1 : Likuiditas berpengaruh positif terhadap nilai perusahaan pada perusahaan manufaktur yang terdaftar di Bursa Efek Indonesia periode tahun 2014-2018

\section{Pengaruh Leverage terhadap Nilai Perusahaan}

Hutang yang semakin besar menyebabkan beban perusahaan menjadi besar karena beban biaya hutang yang harus ditanggung. Semakin besar hutang akan menyebabkan prioritas perusahaan untuk membayar dividend akan semakin kecil karena keuntungan perusahaan berkurang dengan adanya biaya hutang perusahaan (Al Najjar, 2012). Teori trade off menyatakan bahwa peningkatan utang dapat meningkatkan nilai perusahaan apabila belum mencapaititik optimalnya. Penggunaan utang dapat mengurangi beban pajak dan biaya agensi perusahaan (Brigham dan Houston, 2015).

Rumondor (2015) yang mengkaji pengaruh struktur modal, ukuran perusahaan, dan risiko perusahaan terhadap nilai perusahaan pada Sub Sektor Plastik dan Pengemasan di BEI menunjukkan struktur modal berpengaruh positif dan signifikan terhadap nilai perusahaan. Setyabudi (2018) yang menganalisis pengaruh struktur modal terhadap nilai perusahaan pada perusahaan manufaktur yang terdaftar pada bursa efek Indonesia dengan populasi yang digunakan adalah perusahaan manufakture periode 2013-2017 menunjukan Debt to equity ratio berpengaruh signifikan positif terhadap nilai perusahaan.

$\mathrm{H} 2$ : Leverage berpengaruh positif terhadap nilai perusahaan pada perusahaan manufaktur yang terdaftar di Bursa Efek Indonesia periode tahun 2014-2018

\section{Pengaruh Likuiditas terhadap Profitabilitas}

Penurunan rasio aktiva lancar atas total aktiva akan mengakibatkan meningkatnya profitabilitas maupun risiko yang dihadapi oleh perusahaan. Peningkatan profitabilitas ini disebabkan karena lebih banyak modal yang diinvestasikan dalam aktiva tetap yang dapat memberikan profitabilitas yang lebih besar dibandingkan dengan aktiva lancar (Syamsuddin, 2013).

Penelitian yang dilakukan Alicia (2017) bertujuan mengetahui pengaruh likuiditas terhadap rasio pengembalian atas aset pada perusahaan sub sektor semen yang terdaftar di Bursa Efek Indonesia 
periode 2011-2015. Hasil penelitian mengungkapkan bahwa, secara parsial rasio lancar memiliki pengaruh positif dan signifikan terhadap rasio pengembalian atas asset.

Hasil penelitian yang dilakukan oleh Safdar et al., (2016) menyatakan bahwa terdapat hubungan signifikan positif antara current ratio terhadap profitabilitas return on assets (ROA). Dalam penelitian Akoto et al., (2013) pada perusahaan manufaktur di Ghana menyatakan bahwa likuiditas berhubungan secara signifikan positif terhadap ptofitabilitas. Supardi, et al (2018) juga menjelaskan bahwa current ratio berpengaruh secara positif terhadap profitabilitas yang diproksi dengan ROA.

H3 : Likuiditas berpengaruh positif terhadap profitabilitas pada perusahaan manufaktur yang terdaftar di Bursa Efek Indonesia periode tahun 2014-2018

\section{Pengaruh Leverage terhadap Profitabilitas}

Trade-off theory berasumsi bahwa semakin tinggi debt to equity ratio dapat meningkatkan profitabilitas. Pengurangan bunga utang pada penghasilan kena pajak memperkecil proporsi beban pajak sehingga laba bersih setelah pajak menjadi semakin besar dan profitabilitas juga meningkat.

Secara empiric penelitian ini didukung oleh Ashari (2017) dilakukan untuk menguji pengaruh utang terhadap rasio aset (DAR), rasio utang terhadap ekuitas (DER), tingkat leverage keuangan (DFL), rasio utang panjang terhadap ekuitas (LDER), dan rasio perolehan bunga waktu (TIER) pada pengembalian ekuitas (ROE) secara bersamaan dan sebagian dalam perusahaan pariwisata. Analisis regresi linier berganda digunakan sebagai alat analisis data dengan return on equity (ROE) sebagai variabel dependen. Penelitian ini menggunakan data sekunder yang berasal dari laporan keuangan perusahaan pariwisata yang terdaftar di BEI periode 2011-2015. Sampel diperoleh 10 perusahaan dari 23 perusahaan yang terdaftar di BEI. Hasil penelitian ini menunjukkan leverage memiliki hasil positif dan berpengaruh signifikan terhadap profitabilitas.

Studi empiris lain oleh Sari (2019) yang bertujuan untuk mengetahui pengaruh current ratio (CR) dan debt to equity ratio (DER) pada profitabilitas dengan intellectual capital (IC) sebagai pemoderasi. Penelitian dilakukan pada 47 perusahaan properti yang terdaftar di Bursa Efek Indonesia tahun 2014-2016. 
Sampel dipilih 34 sampel perusahaan. Hasil analisis membuktikan bahwa DER berpengaruh positif pada profitabilitas. Penelitian lain yang mendukung dilakukan oleh Mochammad (2016); Marusya dan Magantar (2016) yang DER mempunyai pengaruh signifikan terhadap ROA.

$\mathrm{H} 4$ : Leverage berpengaruh positif
terhadap profitabilitas pada
perusahaan manufaktur yang
terdaftar di Bursa Efek Indonesia
periode tahun 2014-2018

\section{Pengaruh Profitabilitas terhadap Nilai}

\section{Perusahaan}

Banyaknya investor yang membeli saham perusahaan, maka akan menaikkan harga saham perusahaan tersebut sehingga akan meningkatkan nilai perusahaannya. Semakin tinggi rasio ini maka akan semakin baik posisi perusahaan yang berarti semakin besar kemampuan perusahaan untuk menutupi investasi yang digunakan. Hal ini dapat memungkinkan perusahaan untuk membiayai investasi dari dana yang berasal dari sumber internal yang tersedia dalam laba ditahan. Sesuai dengan konsep signaling theory yang menyatakan bahwa profitabilitas akan menjadi sinyal dari manajemen yang menggambarkan prospek perusahaan berdasarkan tingkat profitabilitas yang terbentuk dan secara langsung mempengaruhi nilai perusahan yang dapat dilihat dari harga saham di pasaran. Jadi pengaruh profitabilitas terhadap nilai perusahaan adalah positif.

Hargiansyah (2015) menganalisis pengaruh ukuran perusahaan, leverage dan profitabilitas terhadap nilai perusahaan. Sampel penelitian ditentukan dengan metode stratified random sampling sehingga didapatkan 98 perusahaan manufaktur dengan periode penelitian 2011 sampai 2013. Data laporan keuangan diperoleh dari Bursa Efek Indonesia (BEI), untuk menguji faktor-faktor penentu nilai perusahaan. Hasil penelitian ini memberikan hasil bahwa variabel profitabilitas berpengaruh positif terhadap nilai perusahaan. Penelitian Khumairoh dan Mulyati (2016) dan Maryani (2016) juga memberikan hasil bahwa variabel profitabilitas berpengaruh positif terhadap nilai perusahaan.

H5 : Profitabilitas berpengaruh positif terhadap nilai perusahaan pada perusahaan manufaktur yang terdaftar di Bursa Efek Indonesia periode tahun 2014-2018 


\section{Kerangka Pemikiran}

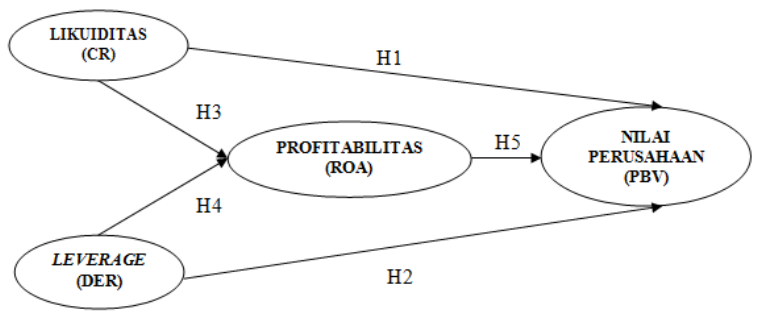

\section{METODOLOGI PENELITIAN}

\section{Populasi dan Sampel}

Populasi adalah sekelompok orang, kejadian atau segala sesuatu yang mempunyai karekteristik tertentu. Populasi pada penelitian ini meliputi seluruh perusahaan manufaktur yang terdaftar di Bursa efek Indonesia (BEI) periode 20142018 berjumlah 144 perusahan.

Sampel adalah bagian dari populasi yang akan dijadikan objek dalam melakukan penelitian dan pengujian data. Metode yang digunakan dalam penarikan sampel ini adalah purpisive sampling. Adapun kriteria perusahaan yang dijadikan sampel dalam penelitian ini adalah :

\section{Tabel 1 Kriteria Penelitian}

\begin{tabular}{clc}
\hline No & \multicolumn{1}{c}{ Kriteria Penelitian } & Jumlah \\
\hline 1 & $\begin{array}{l}\text { Perusahaan manufaktur yang } \\
\text { listing di BEI selama periode } \\
\text { pengamatan 2014-2018 }\end{array}$ & 144 \\
& $\begin{array}{l}\text { Konsisten mempublikasikan } \\
\text { laporan keuangan selama } \\
\text { periode penelitian }\end{array}$ & 127 \\
3 & $\begin{array}{l}\text { Menggunakan laporan keuangan } \\
\text { dalam bentuk IDR }\end{array}$ & 84 \\
4 & $\begin{array}{l}\text { Perusahaan yang mengalami } \\
\text { penurunan nilai perusahaan } \\
\text { selama periode penelitian } \\
\text { Perusahaan yang menyajikan }\end{array}$ & 13 \\
\hline
\end{tabular}

\begin{tabular}{clc}
\hline & data tersedia lengkap & \\
$6 \quad$ Jumlah tahun penelitia & 5 \\
& Jumlah sampel data & 65 \\
\hline
\end{tabular}

Berdasarkan tabel di atas diketahui dari 144 perusahaan yang terdaftar hanya ada 13 perusahaan yang memenuhi kriteria sampling mengalami penurunan nilai perusahaan selama periode 2014-2018. Dengan jumlah tahun penelitian adalah 5 tahun maka jumlah sampel data yang digunakan berjumlah 65 observasi.

\section{Jenis dan Sumber Data}

Jenis data yang digunakan dalam penelitian ini menggunakan data sekunder. Data sekunder adalah data yang telah ada dan tidak perlu dikumpulkan sendiri oleh peneliti (Sekaran, 2015). Data sekunder dalam penelitian ini adalah laporan keuangan tahunan perusahaan yang menjadi sampel penelitian ini pada tahun 2014-2018 yang telah diaudit oleh kantor akuntan publik. Teknik pengumpulan data dilakukan dengan metode dokumentasi dimana data dikumpulkan dari website resmi BEI di www.idx.co.id, dan Indonesian Capital Market Directory.

\section{Teknik Analisis Data}

Teknik analisis data dalam penelitian ini menggunakan analisis statistik deskriptif dan statistik inferensial 
menggunakan analisis regresi linier berganda dengan program SPSS.

\section{HASIL PENELITIAN}

\section{Hasil Statistik Deskriptif}

Analisis statistik deskriptif memberikan gambaran tentang data penelitian yang dilihat dari nilai rata-rata (mean), standar deviasi, maksimum dan minimum data variabel penelitian yang disajikan sebagai berikut :

Tabel 2 Statistik Deskriptif

\begin{tabular}{lrrrr}
\hline & \multicolumn{1}{c}{ Min } & \multicolumn{1}{c}{ Max } & Mean & Std. Deviation \\
\hline CR & 78.61 & 808.89 & 245.73 & 151.56584 \\
DER & .17 & 2.90 & .9297 & .76750 \\
ROA & -2.40 & 16.74 & 4.9417 & 4.34601 \\
PBV & .23 & 4.91 & 1.4203 & 1.08921 \\
Valid N & & & & \\
(listwise) & & & & \\
\hline
\end{tabular}

Sumber : data diolah, 2019.

Likuiditas merupakan rasio yang menggambarkan kemampuan perusahaan dalam memenuhi kewajiban jangka pendeknya yang segera jatuh tempo. Dalam penelitian ini likuiditas yang diproksi menggunakan Current Ratio (CR) diketahui memiliki nilai minimum sebesar 78,61 dan maksimum sebesar 808,89. Hasil ini menunjukan bahwa paling rendah perusahaan manufaktur yang terdaftar di Bursa Efek Indonesia periode tahun 20142018 memiliki asset lancar sebesar 78,61 kali untuk memenuhi hutang jangka pendeknya, dan paling tinggi sebesar 808,89 kali.

Nilai rata-rata yang diperoleh sebesar 245,73 menunjukan dari 13 perusahaan sampel yang diambil rata-rata memiliki nilai asset lancar untuk memenuhi kewajiban jangka pendeknya sebesar 245,73 kali. Nilai standar deviasi sebesar 151,265 yang lebih kecil dibandingkan nilai rata-rata menunjukan bahwa pada periode tahun 2014-2018 perusahaan manufaktur yang sahamnya terdaftar di Bursa Efek Indonesia memiliki kemampuan pemenuhan hutang jangka pendek yang cukup stabil. Perusahaan yang menggunakan likuiditas paling rendah pada penelitian ini adalah PT Indomobil Sukses Internasional Tbk (IMAS) yang terjadi di tahun 2018. Sedangkan perusahaan yang memiliki likuditias paling tinggi adalah PT Lionmesh Prima Tbk (LMSH) yang terjadi pada tahun 2015 .

Leverage merupakan rasio yang digunakan untuk mengukur seberapa besar perusahaan dibiayai dengan utang. Dalam penelitian ini leverage diproksi menggunakan Debt to Equity Ratio (DER). Data pada tabel menunjukan nilai minimum DER sebesar 0,17 dimiliki oleh PT Tunas Alfin Tbk (TALF) di tahun 2016 yang menunjukan bahwa paling rendah 
perusahaan manufaktur yang terdaftar di Bursa Efek Indonesia menggunakan hutang sebesar 0,17 kali modal yang dimiliki. Nilai maksimum sebesar 2,90 dimiliki oleh PT Indomobil Sukses Internasional Tbk (IMAS) pada tahun 2018 menunjukan bahwa paling tinggi perusahaan sampel menggunakan hutang hingga 2,9 kali total modal perusahaan. Rata-rata leverage sebesar 0,92 menunjukan bahwa rata-rata perusahaan manufaktur menggunakan hutang untuk biaya operasional kurang dari $1 \%$ modal perusahaan. Standar deviasi sebesar 0,76 yang lebih rendah dibandingkan nilai ratarata menunjukan bahwa leverage perusahaan manufaktur selama tahun 2014-2018 cukup stabil.

Profitabilitas merupakan rasio untuk mengukur efektifitas manajemen secara keseluruhan yang di tunjukan oleh besar kecilnya tingkat keuntungan yang di peroleh dalam hubungannnya dengan penjualan maupun investasi. Data pada Tabel 4.3 diketahui nilai profitabilitas yang diproksi menggunakan Return on Asset (ROA) memiliki rata-rata 4,94 yang berarti rata-rata profitabilitas pada perusahaan manufaktur pada tahun 2014-2018 adalah $4,94 \%$ dari total asset yang dimiliki. Nilai minimum dimiliki pada PT Malindo Feedmill Tbk (MAIN) di tahun 2014 dengan nilai ROA sebesar -2,40. Nilai maksimum dimiliki PT Ultrajaya Milk Industry \& Trading Co Tbk (ULTJ) di tahun 2016 dengan nilai ROA sebesar 16,74. Hasil ini menunjukan kemampuan perusahaan manufaktur dalam menghasilkan profitabilitas berbeda-beda. Selama tahun 2014-2018, perusahaan manufaktur ada yang mengalami kerugian hingga $-2,40 \%$ sementara perusahaan lainnya ada yang berhasil memperoleh keuntungan dengan angka yang cukup besar mencapai $16,74 \%$. Nilai standar deviasi 4,34 yang lebih kecil dibandingkan nilai rata-rata menunjukan bahwa kemampuan pencapaian profitabilitas pada perusahaan sampel cukup stabil.

Nilai perusahaan merupakan perkiraan laba per saham untuk memaksimalkan harga saham suatu perusahaan, yang dalam penelitian ini dilihat dari rasio Price to Book Value (PBV). Berdasarkan data yang ada pada Tabel 4.4 terlihat rata-rata nilai perusahaan manufaktur selama periode 2014-2018 adalah sebesar 1,42 artinya rata-rata pasar menghargai nilai saham perusahaan manufaktur sebesar 1,42 kali dari nilai buku per lembar yang ditetapkan perusahaan. Hasil tersebut menunjukkan bahwa perusahaan manufaktur secara 
umum memiliki nilai perusahaan yang masih rendah. Nilai minimum 0,23 dimiliki oleh PT Ricky Putra Globalindo Tbk (RICY) di tahun 2017 dan maksimum sebesar 4,91 dimiliki oleh PT PT Ultrajaya Milk Industry \& Trading Co Tbk (ULTJ) di tahun 2014. Hasil ini menunjukan nilai perusahaan manufaktur cukup beragam. Sebagian perusahaan ada yang memiliki nilai perusahaan sangat rendah kurang dari 1 kali nilai buku dan sebagian lainnya memiliki nilai perusahaan yang cukup tinggi hingga 4,91 kali nilai buku sahamnya. Standar deviasi yang diperoleh sebesar 1,08 yang lebih kecil dibandingkan rata-rata menunjukan bahwa kepemilikan rasio PBV pada perusahaan manufaktur cukup stabil.

\section{Hasil Uji Asumsi Klasik}

\section{Uji Normalitas}

Berikut ini disajikan data hasil pengujian normalitas data menggunakan Kolmogorov-Smirnov (K-S) :

\section{Tabel 3 Uji Normalitas Residual Regresi}

CR, DER, ROA $\rightarrow$ PBV

\begin{tabular}{llr}
\hline & & \multicolumn{1}{c}{$\begin{array}{r}\text { Unstandardized } \\
\text { Residual }\end{array}$} \\
\hline $\mathrm{N}$ & & 65 \\
Normal & Mean & .0000000 \\
Paramet & Std. Deviation & .85571488 \\
ers & & \\
Most & Absolute & .208 \\
Extreme & Positive & .208 \\
\hline
\end{tabular}

\begin{tabular}{lr}
\hline Differenc Negative & -.081 \\
es & \\
Kolmogorov-Smirnov Z & 1.680 \\
Asymp. Sig. (2-tailed) & .007 \\
a. Test distribution is Normal. & \\
b. Calculated from data. &
\end{tabular}

Sumber : data diolah, 2019.

Hasil pengujian normalitas pada tabel di atas menunjukan nilai signifikansi (asymp sig. 2 tailed) sebesar 0,007. Data dinyatakan terdisitribusi normal apabila memiliki nilai signifikasi (asymp sig. 2 tailed) > 0,05 (Ghozali, 2015). Merujuk pada pendapat ini maka dapat disimpulkan bahwa hasil uji normalitas pada model regresi $\mathrm{CR}, \mathrm{DER}, \mathrm{ROA} \rightarrow \mathrm{PBV}$ dinyatakan gagal.

Oleh karena kondisi ini maka data ditransformasi menjadi nilai Logaritma Natural (LN) dimana selanjutnya nama variabel berubah menjadi LNCR, LNDER, LNROA dan LNPBV. Berdasarkan hasil transformasi data diketahui terdapat 7 data yang ekstrem yaitu pada n6, n8, n19, n21, n34, n47 dan n54. Data-data ekstrem ini perlu dihapus karena akan membuat pengolahan data menjadi bermasalah. Dari jumlah data awal sebanyak 65 setelah dikurangi data ekstrem maka data yang dapat diolah berjumlah 58 .

Selanjutnya dilakukan pengujian ulang pada normalitas data pada model 
residual CR, DER, ROA terhadap PBV menggunakan residual dari data yang sudah ditransformasi dan dikurangi data ekstrem. Berikut ini adalah hasilnya :

Tabel 4 Uji Normalitas Residual Regresi LNCR, LNDER, LNROA $\rightarrow$ LNPBV

\begin{tabular}{llr}
\hline & & $\begin{array}{r}\text { Unstandardize } \\
\text { d Residual }\end{array}$ \\
\hline $\mathrm{N}$ & Mean & 58 \\
Normal Parameters ${ }^{\mathrm{a}, \mathrm{b}}$ & Std. & .45931797 \\
& Deviation & \\
Most Extreme Differences & Absolute & .065 \\
& Positive & .065 \\
& Negative & -.052 \\
Kolmogorov-Smirnov Z & & .495 \\
Asymp. Sig. (2-tailed) & & .967 \\
a. Test distribution is Normal. & \\
b. Calculated from data. & & \\
\hline
\end{tabular}

Sumber : data diolah, 2019.

Hasil pengujian normalitas pada model residual regresi LNCR, LNDER, LNROA $\rightarrow$ LNPBV pada tabel di atas menunjukan nilai (asymp sig. 2 tailed) sebesar 0,967 . Oleh karena nilai signifikasi yang diperoleh > 0,05 maka data dinyatakan sudah terdistribusi normal.
Tabel 5 Uji Normalitas Residual Regresi LNCR, LNDER $\rightarrow$ LNROA

\begin{tabular}{llr}
\hline \multicolumn{2}{c}{ One-Sample Kolmogorov-Smirnov Test } \\
& & $\begin{array}{c}\text { Unstandardized } \\
\text { Residual }\end{array}$ \\
& Mean & 58 \\
$\mathrm{~N}$ & Std. & .0000000 \\
& Deviation & .76917897 \\
Most Extreme Differences & Absolute & .136 \\
& Positive & -.136 \\
& Negative & 1.038 \\
Kolmogorov-Smirnov Z & & .232 \\
Asymp. Sig. (2-tailed) & &
\end{tabular}

a. Test distribution is Normal.

b. Calculated from data

Sumber : data diolah, 2019.

Hasil uji normalitas model residual regresi LNCR, LNDER $\rightarrow$ LNROA pada tabel di atas juga telah menunjukan nilai (asymp sig. 2 tailed) sebesar 0,232 > signifikasi 0,05 yang artinya data dinyatakan sudah terdistribusi normal.

\section{Uji Multikolinieritas}

Tabel 6 Multikolinieritas LNCR, LNDER, LNROA $\rightarrow$ LNPBV

\begin{tabular}{llcc}
\hline \multicolumn{4}{c}{ Coefficients $^{\mathbf{a}}$} \\
Model & \multicolumn{2}{c}{$\begin{array}{c}\text { Collinearity Statistics } \\
\text { Tolerance }\end{array}$} & VIF \\
\hline 1 & & & \\
& & & \\
& & & \\
& LNCR & .141 & 7.088 \\
LNDER & .128 & 7.809 \\
LNROA & .745 & 1.343 \\
\hline a. Dependent Variable: LNPBV & &
\end{tabular}

Sumber : data diolah, 2019. 
Model regresi dinyatakan bebas multikolinieritas apabila mempunyai nilai Tolerance $\geq 0,1$ atau sama dengan nilai VIF $\leq 10$ (Ghozali, 2015). Hasil perhitungan nilai Tolerance dan VIF pada Tabel 4.8 diatas menunjukkan bahwa semua variabel independen memiliki nilai Tolerance diatas 0,1 dan nilai VIF dibawah 10. Maka dapat disimpulkan bahwa tidak terjadi multikolinieritas dalam hubungan antar variabel LNCR, LNDER dan LNROA pada model regresi.

Tabel 7 Multikolinieritas LNCR, LNDER $\rightarrow$ LNROA

\begin{tabular}{|c|c|c|c|}
\hline \multicolumn{4}{|c|}{ Coefficients $^{a}$} \\
\hline & & \multicolumn{2}{|c|}{ Collinearity Statistics } \\
\hline Model & & Tolerance & VIF \\
\hline \multirow[t]{3}{*}{1} & (Constant) & & \\
\hline & LNCR & .144 & 6.922 \\
\hline & LNDER & .144 & 6.922 \\
\hline
\end{tabular}

Sumber : data diolah, 2019.

Pada tabel di atas juga ditunjukan bahwa antara variabel LNCR dan LNDER tidak terjadi multikolonieritas karena seluruh telah memperoleh nilai Tolerance diatas 0,1 dan nilai VIF dibawah 10.

\section{Uji Autokorelasi}

Tabel 7 Durbin Watson Test LNCR, LNDER, LNROA $\rightarrow$ LNPBV

\begin{tabular}{lr}
\hline Model & \multicolumn{1}{c}{ Durbin-Watson } \\
\hline 1 & 2.291 \\
\hline
\end{tabular}

Berdasarkan data diperoleh nilai DW sebesar 2,291. Pada tabel dengan $\mathrm{df}=58$ dan $\mathrm{k}=3$ diketahui nilai $\mathrm{dL}$ sebesar 1,4692 dan dU sebesar 1,6860. Berdasarkan kriteria pengambilan keputusan poin (e) yang menyatakan tidak ada autokorelasi positif maupun negative apabila dU $(1,6860)<$ DW $(2,291)<4-d U$ (2,314). Dengan demikian model regresi LNCR, LNDER, LNROA $\rightarrow$ LNPBV dinyatakan terbebas dari gejala autokorelasi baik positif maupun negatif.

\section{Tabel 8 Durbin Watson Test LNCR, LNDER $\rightarrow$ LNROA

\begin{tabular}{lr}
\hline Model & Durbin-Watson \\
\hline 1 & 1.678
\end{tabular}

Berdasarkan data diperoleh nilai DW sebesar 1,678. Pada tabel dengan $\mathrm{df}=58$ $\mathrm{k}=2$ diketahui nilai $\mathrm{dL}$ sebesar 1,5052 dan dU sebesar 1,6475. Hasil ini juga merujuk pada keputusan poin (e) yang menyatakan tidak ada autokorelasi positif maupun negative karena nilai dU $(1,6475)<$ DW $(1,678)<4-d U(2,3525)$. Dengan demikian model regresi LNCR, LNDER $\rightarrow$ LNROA 
juga dinyatakan terbebas dari gejala autokorelasi baik positif maupun negatif.

\section{Uji Heteroskedastisitas}

Scatterplot

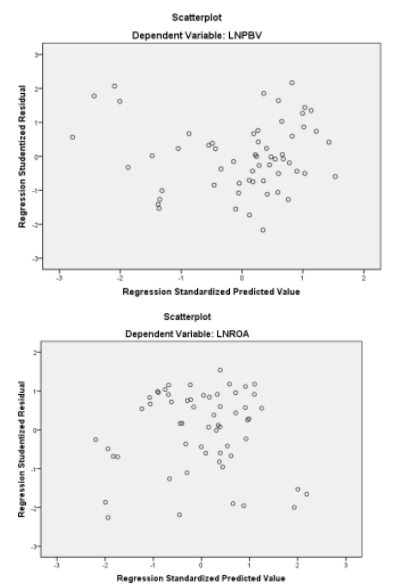

Sumber : data diolah, 2019.

Berdasarkan gambar di atas terlihat titik menyebar di atas dan dibawah angka 0 pada sumbu $\mathrm{Y}$ yang mengindikasikan tidak terjadinya heteroskedasitas. Dengan demikian model regresi dinyatakan juga terbebas dari gejala heteroskedastisitas dan layak dilanjutkan dalam proses selanjutnya.

\section{Hasil Analisis Jalur}

Analisis jalur dalam penelitian digunakan untuk menguji pengaruh variabel independen terhadap variabel dependen apakah masing-masing variabel independen berhubungan positif atau negatif. Dari olah data yang dilakukan, diperoleh model persamaan struktur sebagai berikut :

LNPBV = -0,782 LNCR - 0,550 LNDER

$+0,775$ LNROA + 0,591

Penjelasan :

1. Diketahui nilai koefisien standardized LNCR adalah 0,782 . Tanda negatif ini menunjukan setiap kenaikan pada likuiditas sebesar 1 satuan dengan asumsi variabel LNDER dan LNROA tetap, maka akan menurunkan nilai perusahaan sebesar 0,782 satuan begitu juga sebaliknya. Nilai sig 0,001 $<0,05$ menunjukan pengaruh antara LNCR adalah signifikan, artinya likuiditas berpengaruh negatif dan signifikan terhadap nilai perusahaan.

2. Koefisien standardized LNDER diperoleh sebesar $-0,550$. Tanda negatif ini menunjukan setiap kenaikan pada leverage sebesar 1 satuan dengan asumsi variabel LNCR dan LNROA tetap, maka akan menurunkan nilai perusahaan sebesar 0,550 satuan begitu juga sebaliknya. Nilai sig $0,018<0,05$ menunjukan pengaruh antara LNDER adalah signifikan, artinya leverage berpengaruh negatif dan signifikan terhadap nilai perusahaan. 
3. Koefisien standardized LNROA diperoleh sebesar 0,775 . Tanda positif ini menunjukan setiap kenaikan pada profitabilitas sebesar 1 satuan dengan asumsi variabel LNCR dan LNDER tetap, maka akan meningkatkan nilai perusahaan sebesar 0,775 satuan begitu juga sebaliknya. Nilai sig $0,000<0,05$ menunjukan pengaruh antara LNROA adalah signifikan, artinya profitabilitas berpengaruh positif dan signifikan terhadap nilai perusahaan.

4. Nilai standar eror sebesar 0,591 diperoleh dari $\sqrt{ } 1-R^{2}=\sqrt{ } 1-0,650$.

5.

\section{LNROA = -0,351 LNCR - 0,812 LNDER $+\mathbf{0 , 8 6 3}$}

Penjelasan :

a. Diketahui nilai koefisien standardized LNCR adalah $-0,351$. Tanda negatif ini menunjukan setiap kenaikan pada likuiditas sebesar 1 satuan dengan asumsi variabel LNDER tetap, maka akan menurunkan profitabilitas sebesar 0,351 satuan begitu juga sebaliknya. Nilai sig 0,256>0,05 menunjukan pengaruh antara LNCR adalah tidak signifikan, artinya likuiditas tidak berpengaruh terhadap profitabilitas.

b. Koefisien standardized LNDER diperoleh sebesar $-0,812$. Tanda negatif ini menunjukan setiap kenaikan pada leverage sebesar 1 satuan dengan asumsi variabel LNDER tetap, maka akan menurunkan profitabilitas sebesar 0,812 satuan begitu juga sebaliknya. Nilai sig $0,010<0,05$ menunjukan pengaruh antara LNDER adalah signifikan, artinya leverage berpengaruh negatif terhadap profitabilitas.

c. Nilai standar eror sebesar 0,863 diperoleh dari $\sqrt{ } 1-\mathrm{R}^{2}=\sqrt{ } 1-0,225$.

Dari hasil kedua analisis jalur tersebut, maka dapat dibuat gambaran model analisis jalur sebagai berikut:

\section{Model Analisis Jalur}

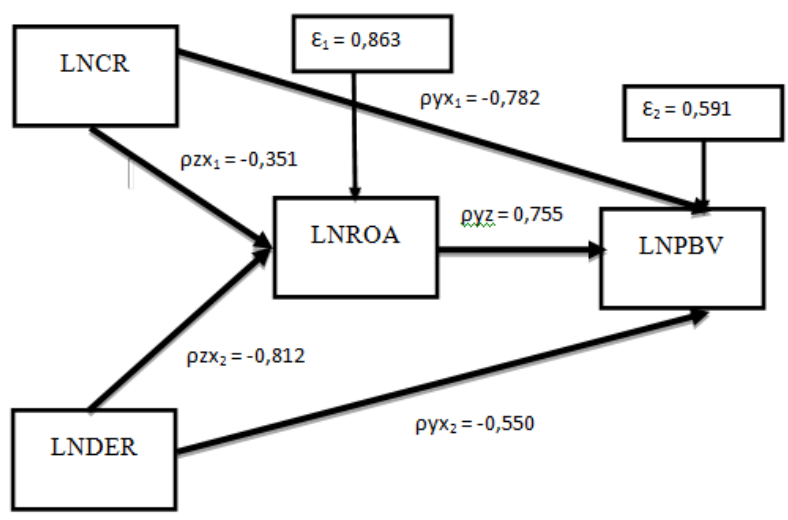

Sumber : data diolah SPSS, 2019 


\section{Hasil Uji Hipotesis}

1. Pengaruh Likuiditas terhadap Nilai Perusahaan

Hasil analisis menunjukkan bahwa nilai $\mathrm{t}$ hitung hipotesis 1 diperoleh sebesar $-3,647$ dan sig 0,001. Nilai $t$ pada tabel dengan df $=58-1$ uji satu pihak dengan sig 5\% adalah 1,672. Hasil ini menunjukan bahwa t hitung 3,647> t tabel -1,672 dan sig 0,001 < 0,05 yang artinya berpengaruh signifikan. Nilai koefisien standardized LNCR ( $\beta 1)$ sebesar 0,782 dan $\mathrm{t}$ hitung yang bertanda negatif menunjukan bahwa likuiditas berpengaruh negatif signifikan terhadap nilai perusahaan. Dengan demikian arah hubungan likuiditas terhadap nilai perusahaan hasil uji $t$ yang berkebalikan dengan hipotesis menunjukan bahwa Hal ditolak, karena likuiditas justru terbukti berpengaruh negatif signifikan terhadap nilai perusahaan.

\section{Pengaruh Leverage terhadap Nilai}

\section{Perusahaan}

Hasil analisis menunjukkan bahwa nilai $\mathrm{t}$ hitung hipotesis 2 diperoleh sebesar $-2,446$ dan sig 0,018. Nilai $t$ pada tabel dengan df $=58-1$ uji satu pihak dengan sig 5\% adalah 1,672. Hasil ini menunjukan bahwa t hitung - $2,446>\mathrm{t}$ tabel $-1,672$ dan sig $0,018<$ 0,05 yang artinya berpengaruh signifikan. Nilai koefisien standardized LNDER ( $\beta 2)$ sebesar 0,550 dan nilai t hitung yang bertanda negatif menunjukan bahwa leverage berpengaruh signifikan secara negatif terhadap nilai perusahaan. Dengan demikian arah hubungan leverage terhadap nilai perusahaan hasil uji $\mathrm{t}$ yang berkebalikan dengan hipotesis menunjukan bahwa Ha2 ditolak, karena leverage justru terbukti berpengaruh negatif signifikan terhadap nilai perusahaan.

\section{Pengaruh Likuiditas terhadap} Profitabilitas

Hasil analisis menunjukkan bahwa nilai $\mathrm{t}$ hitung hipotesis 3 diperoleh sebesar $-1,147$ dan sig 0,256. Nilai t pada tabel dengan df $=58-1$ uji satu pihak dengan sig 5\% adalah 1,672. Hasil ini menunjukan bahwa t hitung $1,147<\mathrm{t}$ tabel $-1,672$ dan sig 0,256 > 0,05 yang artinya tidak signifikan. Dengan demikian hasil ini menunjukan bahwa likuiditas tidak berpengaruh terhadap profitabilitas perusahaan, $\mathbf{H a 3}$ ditolak. 
4. Pengaruh Leverage terhadap Profitabilitas

Hasil analisis menunjukkan bahwa nilai t hitung hipotesis 4 diperoleh sebesar $-2,653$ dan sig 0,010 . Nilai $t$ pada tabel dengan $\mathrm{df}=58-1$ uji satu pihak dengan sig 5\% adalah 1,672. Hasil ini menunjukan bahwa t hitung $2,653>\mathrm{t}$ tabel 1,672 dan sig 0,010 > 0,05 yang artinya berpengaruh signifikan. Nilai koefisien standardized LNDER ( $\beta 4)$ sebesar 0,812 dan $t$ hitung yang bertanda negatif menunjukan bahwa leverage berpengaruh negatif signifikan terhadap profitabilitas. Dengan demikian arah hubungan leverage terhadap profitabilitas hasil uji t yang berkebalikan dengan hipotesis menunjukan bahwa $\mathrm{Ha} 4$ ditolak, karena leverage justru terbukti berpengaruh negatif signifikan terhadap profitabilitas.

\section{Pengaruh Profitabilitas terhadap} Nilai Perusahaan

Hasil analisis menunjukkan bahwa nilai $\mathrm{t}$ hitung hipotesis 5 diperoleh sebesar 8,308 dan sig 0,000 . Nilai $t$ pada tabel dengan $\mathrm{df}=58-1$ uji satu pihak dengan sig 5\% adalah 1,672. Hasil ini menunjukan bahwa t hitung $8,308>\mathrm{t}$ tabel 1,672 dan sig $0,000<$
0,05 yang artinya berpengaruh signifikan. Hasil ini menunjukan bahwa profitabilitas berpengaruh positif signifikan terhadap nilai perusahaan, yang artinya Ha5 diterima.

Berdasarkan hasil uji hipotesis yang telah diuraikan tersebut, maka dapat disimpulkan hasil pengujian hipotesis :

Tabel 9 Kesimpulan Uji Hipotesis

\begin{tabular}{lccl}
\hline Hipotesis & $\begin{array}{c}\text { T } \\
\text { hitung }\end{array}$ & Sig. & \multicolumn{1}{c}{ Hasil } \\
\hline CR- PBV & -3.647 & 0.001 & $\begin{array}{l}\text { Berpengaruh } \\
\text { negatif signifikan }\end{array}$ \\
$\begin{array}{l}\text { DER - } \\
\text { PBV }\end{array}$ & -2.446 & 0.018 & $\begin{array}{l}\text { Berpengaruh } \\
\text { negatif signifikan }\end{array}$ \\
CR- ROA & -1.147 & 0.256 & $\begin{array}{l}\text { Tidak } \\
\text { berpengaruh } \\
\text { Berpengaruh }\end{array}$ \\
DER - & -2.653 & 0.010 & $\begin{array}{l}\text { negatif signifikan } \\
\text { ROA }\end{array}$ \\
$\begin{array}{l}\text { ROA - } \\
\text { PBV }\end{array}$ & 8.308 & 0.000 & $\begin{array}{l}\text { Berpengaruh } \\
\text { positif signifikan }\end{array}$ \\
\hline
\end{tabular}

Hasil Uji Mediasi dengan Sobel Test

\section{Mediasi 1}

LNCR $\rightarrow$ LNPBV

$=-$

0,303

$\mathrm{LNCR} \rightarrow \mathrm{LNROA} \rightarrow \mathrm{LNPBV} \quad=$

0,340

Total LNCR $\rightarrow$ LNPBV

$=$

0,037

Dari hasil hitung di atas diketahui koefisien pengaruh tidak langsung likuiditas terhadap nilai perusahaan melalui profitabilitas adalah sebesar 0,340. Nilai total pengaruh likuiditas terhadap 
nilai perusahaan diperoleh sebesar 0,037 . Untuk meyakinkan ada tidaknya mediasi dilakukan pengujian sobel test menggunakan aplikasi sebagai berikut:

\section{Tabel 10 Hasil Uji Mediasi Sobel}

\section{Test 1}

\begin{tabular}{|c|c|c|c|c|}
\hline Input: & & Test statistic: & Std. Error: & $p$-value: \\
\hline a 0.400 & Sobel test: & 0.41598894 & 0.81925255 & 0.6774181 \\
\hline b 0.852 & Aroian test: & 0.34134031 & 0.9984171 & 0.73284741 \\
\hline$s_{\mathrm{a}} 0.916$ & Goodman test: & 0.57978574 & 0.58780335 & 0.56205912 \\
\hline$s_{\mathrm{b}} 0.623$ & Reset all & & Calculate & \\
\hline
\end{tabular}

Sumber:

http://quantpsy.org/sobel/sobel.htm

Hasil uji sobel test tersebut menunjukan nilai t statistic sebesar 0,415 dan $p$ value sebesar 0,677. Dibandingkan dengan nilai t tabel 1,672 maka hasil uji sobel juga menunjukan bahwa profitabilitas tidak mampu memediasi pengaruh likuiditas terhadap nilai perusahaan. Hal ini sejalan dengan Adita dan Mawardi (2018) yang menunjukan profitabilitas tidak memediasi pengaruh $\mathrm{CR}$ terhadap PBV. Kondisi CR yang besar menunjukkan perusahaan banyak memiliki aset lancar dibanding hutang lancarnya. Perusahaan lebih banyak menumpuk aset dan kurang efektif dalam mengkonversi aset lancar kedalam penjualan atau pendapatan sehingga menjadikan investor kurang tertarik dan membuat nilai perusahaan akan menjadi menurun.

\section{Mediasi 2}

LNDER $\rightarrow$ LNPBV

$=$

0,198

LNDER $\rightarrow$ LNROA $\rightarrow$ LNPBV

0,402

LNDER $\rightarrow$ LNPBV

0,204

Dari hasil hitung di atas diketahui koefisien pengaruh tidak langsung leverage terhadap nilai perusahaan melalui profitabilitas adalah sebesar -0,402. Nilai total pengaruh leverage terhadap nilai perusahaan diperoleh sebesar -0,204.

\section{Tabel 11 Hasil Uji Mediasi Sobel}

\section{Test 2}

\begin{tabular}{|c|c|c|c|c|}
\hline Input: & & Test statistic: & Std. Error: & $p$-value: \\
\hline a -0.487 & Sobel test: & -0.51011158 & 0.78953118 & 0.60997329 \\
\hline b 0.827 & Aroian test: & $:-0.41221869$ & 0.97702751 & 0.68017914 \\
\hline$s_{\mathrm{a}} 0.872$ & Goodman test: & $:-0.74514668$ & 0.54049627 & 0.45618305 \\
\hline$s_{\mathrm{b}} 0.660$ & Reset all & & Calculate & \\
\hline
\end{tabular}

Sumber

http://quantpsy.org/sobel/sobel.htm

Hasil uji sobel test tersebut menunjukan nilai $\mathrm{t}$ statistic sebesar $-0,510$ dan $p$ value sebesar 0,609. Dibandingkan dengan nilai $\mathrm{t}$ tabel 1,672 maka hasil uji sobel juga menunjukan bahwa profitabilitas tidak mampu memediasi pengaruh leverage terhadap nilai perusahaan. Hal ini sejalan dengan Adita dan Mawardi (2018) yang menunjukan profitabilitas tidak memediasi 
Universitas Banten Jaya

pengaruh struktur modal terhadap nilai perusahaan.

\section{Pengaruh Likuiditas Terhadap Nilai}

\section{Perusahaan}

Hasil pengujian hipotesis likuiditas terhadap nilai perusahaan dinyatakan ditolak karena likuiditas terbukti berpengaruh negatif dan signifikan terhadap nilai perusahaan. Hasil dikarenakan semakin tinggi likuiditas perusahaan yang diatas titik optimal justru akan menurunkan nilai perusahaan, karena adanya aset/kas menganggur yang tidak dimanfaatkann oleh manajemen perusahaan dalam kegiatan operasionalnya.

Hasil penelitian ini sejalan dengan Ananda (2015), Hasania, et al (2016), Sutrisno dan Yulianeu (2017) yang menemukan likuiditas dengan current ratio berpengaruh negatif terhadap nilai perusahaan. Selain itu seorang investor dalam melakukan investasi tidak memperhatikan faktor likuiditas yang dimiliki perusahaan karena rasio ini hanya menunjukan kemampuan perusahaan untuk menutup hutang jangka pendek perusahaan.

Implikasi penelitian ini adalah nilai rasio likuiditas yang semakin tinggi di atas titik optimal akan menurunkan nilai perusahaan, karena dianggap sebagai sinyal buruk oleh investor. Dalam hal ini investor akan mempersepsi adanya aset/kas menganggur yang tidak dimanfaatkan oleh manajemen perusahaan dalam kegiatan operasionalnya.

\section{Pengaruh Leverage terhadap Nilai Perusahaan}

Berdasarkan hasil uji hipotesis 2 ditolak karena menunjukan leverage berpengaruh signifikan secara negatif terhadap nilai perusahaan. Semakin tinggi nilai hutang yang digunakan perusahaan dibandingkan modalnya maka cenderung akan menurunkan persepsi harga saham sehingga nilai perusahaan ikut menurun.

Hasil penelitian ini bertolak belakang dengan trade of theory yang menyatakan adanya hubungan positif antara hutang dengan nilai perusahaan. Namun demikian hasil penelitian sejalan dengan teori sinyal yang menganggap besarnya jumlah hutang perusahaan merupakan sinyal buruk bagi investor karena beresiko menimbulkan kebangkrutan. Penelitian yang mendukung diantaranya dilakukan oleh Sitepu dan Wibisono (2014); Suffah dan Riduwan (2016); dan Nurminda et al (2017) yang menunjukan adanya pengaruh negatif rasio leverage terhadap nilai perusahaan. 
Pengaruh Likuiditas terhadap Profitabilitas

Hasil analisis pengujian hipotesis menunjukkan ditolak yaitu tidak terdapat pengaruh likuiditas terhadap profitabilitas perusahaan. Penelitian ini sejalan dengan penelitian yang dilakukan oleh Sanjaya (2015) yang menjelaskan bahwa Current Ratio (CR) tidak berpengaruh terhadap profitabilitas. Sutrisno dan Yulianeu (2017) dalam penelitiannya juga menemukan tidak ada pengaruh likuiditas terhadap profitabilitas.

Penempatan dana yang terlalu besar pada sisi aktiva memiliki dua efek yang berlainan. Disatu sisi, likuiditas perusahaan semakin baik. Namun di sisi lain, perusahaan kehilangan kesempatan untuk mendapatkan tambahan laba, karena dana yang seharusnya digunakan untuk investasi yang menguntungkan perusahaan, dicadangkan untuk memenuhi likuiditas.

\section{Pengaruh Leverage terhadap Profitabilitas}

Tingkat rasio hutang yang tinggi akan mempengaruhi besar kecilnya laba bagi perusahaan, yang mencerminkan kemampuan perusahaan dalammemenuhi semua kewajibannya yang ditunjukkan dengan beberapa bagianmodal sendiri yang digunakan untuk membayar seluruh kewajibannya. Hal ini dikarenakan semakin besar penggunaan utang maka akan semakin besar kewajibannya.

Hasil analisis menunjukkan hipotesis 4 ditolak karena menunjukan leverage berpengaruh signifikan secara negatif terhadap profitabilitas perusahaan. Hasil penelitian ini didukung oleh penelitian Nurcahayani (2014) yang mengungkapkan bahwa variabel Struktur modal yang diproksikan oleh Debt To Equity Ratio (DER) berpengaruh negatif terhadap profitabilitas. Sama hasilnya dengan penelitian yang dilakukan oleh Rifai, et al (2013) yang menyatakan bahwa variabel struktur modal terdapat pengaruh dan negatif terhadap profitabilitas.

Besarnya profitabilitas modal sendiri selain dipengaruhi ekonomi juga dipengaruhi oleh struktur modal, struktur modal dalam hal ini adalah rasio hutang jangka panjang dengan modal sendiri. Pengaruh negatif terjadi dalam keadaan profitabilitas ekonomi lebih kecil dari tingkat bunga sehingga besarnya hutang akan menurunkan laba perusahaan.

\section{Pengaruh Profitabilitas terhadap Nilai}

\section{Perusahaan}

Hasil analisis uji hipotesis 5 menunjukkan diterima yang artinya profitabilitas berpengaruh positif signifikan terhadap nilai perusahaan. 
Semakin tinggi profitabilitas maka semakin tinggi nilai perusahaan.

$$
\text { Profitabilitas menunjukan }
$$

keuntungan bersih yang dapat dihasilkan oleh perusahaan pada saat menjalankan operasinya. Semakin besar keuntungan bersih yang diperoleh perusahaan, semakin besar kemampuan perusahaan membagi dividen kepada para pemegang saham. Semakin besar dividen yang dibagi, akan semakin tinggi nilai perusaahaannya. Selain profit yang tinggi memberikan prospek yang baik terhadap perusahaan, profit perusahaan yang tinggi akan memicu investor dalam meningkatkan permintaan saham. Dari permintaan saham yang meningkat ini menyebabkan nilai perusahaan meningkat pula.

Tingginya minat investor untuk menanamkan modalnya pada perusahaan dengan rasio profitabilitas yang tinggi, akan meningkatkan harga saham sehingga akan meningkatkan nilai perusahaan. Beberapa penelitian terdahulu yang mendukung diantaranya dilakukan Vaeza dan Hapsari (2014); Pratiwi dan Rahayu (2014); Sedana (2015); Hargiyansyah (2015) karena menunjukan adanya pengaruh positif profitabilitas terhadap nilai perusahaan.

\section{KESIMPULAN DAN SARAN}

\section{Kesimpulan}

Berdasarkan hasil penelitian diketahui bahwa dapat ditarik sebuabh kesimpulan penelitian sebagai berikut :

1. Likuiditas berpengaruh negatif dan signifikan terhadap nilai perusahaan. Tingginya nilai likuiditas dianggap sebagai sinyal buruk oleh investor karena banyaknya dana menganggur yang disiapkan oleh perusahaan yang membuat harga saham menjadi turun dan nilai perusahaan pun turun.

2. Leverage berpengaruh negatif dan signifikan terhadap nilai perusahaan. Semakin besar perusahaan menggunakan hutang maka akan semakin tinggi resiko kebangkrutan yang dihadapi sehingga menurunkan persepsi investor atas harga saham perusahaan.

3. Likuiditas tidak berpengaruh terhadap profitabilitas. Tingginya likuiditas tidak akan mempengaruhi laba perusahaan.

4. Leverage berpengaruh negatif dan signifikan terhadap profitabilitas. Besarnya nilai hutang yang digunakan perusahaan dan apabila selisih nilai bunganya besar maka akan menurunkan laba yang diperoleh perusahaan. 
5. Profitabilitas berpengaruh positif terhadap nilai perusahaan. Laba yang tinggi menjadi sinyal baik kinerja perusahaan dalam mengelola keuangan sehingga menimbulkan persepsi investor yang positif atas harga saham yang akhirnya ikut meningkatkan nilai perusahaan.

\section{Saran}

Berdasarkan kesimpulan yang diuraikan tersebut, maka dapat diberikan beberapa saran manajerial maupun empirik bagi penelitian ini sebagai berikut :

\section{Saran Manajerial}

1. Bagi perusahaan disarankan mengefisiensikan nilai rasio likuiditas yang dimiliki agar tidak menimbulkan dampak buruk bagi persepsi investor karena hasil penelitian menunjukan signifikannya pengaruh likuiditas dalam penurunan nilai perusahaan.

2. Bagi perusahaan disarankan untuk dapat memperhatikan tingkat rasio leverage yang ada saat ini ataupun keputusan pendanaan dengan hutang yang akan dilakukan di masa depan secara lebih proporsional agar tidak dianggap menjadi sinyal buruk yang beresiko menimbulkan kerugian pada perusahaan dan membuat harga saham maupun laba perusahaan menjadi rendah.

3. Bagi perusahaan disarankan untuk semakin meningkatkan nilai rasio profitabilitas dengan meningkatkan nilai laba bersih yang dimiliki. Hal ini akan menjadi sinyal positif terkait kinerja perusahaan yang dapat membuat harga saham menjadi meningkat dan meningkatkan nilai perusahaan.

4. Bagi perusahaan disarankan memperhatikan berbagai faktor lainnya yang dapat menimbulkan persepsi buruk dari investor atas kondisi perusahaan agar tetap menjaga nilai perusahaan yang stabil.

\section{Saran Empiris}

1. Bagi penelitian selanjutnya, disarankan agar mengambil objek penelitian dengan jumlah sampel yang lebih luas lagi untuk menghasilkan hasil penelitian lebih kompleks.

2. Bagi penelitian selanjutnya juga disarankan agar menggunakan proksi lainnya untuk mengukur variabelvariabel penelitian yang digunakan agar dapat membuktikan hasil yang berbeda sesuai kondisi yang ada di perusahaan. 


\section{Keterbatasan}

Adapun beberapa keterbatasan dalam penelitian ini yaitu :

1. Penelitian ini terbatas dalam jumlah sampel yang digunakan.

2. Penelitian ini hanya menggunakan 1 proksi untuk mengukur masing-masing variabel yang digunakan sehingga analisis data terbatas hanya pada lingkup pengukuran yang digunakan.

\section{DAFTAR PUSTAKA}

Alicia. 2017. Pengaruh Likuiditas Terhadap Profitabilitas Pada Perusahaan Sub Sektor Semen Yang Terdaftar Di Bursa Efek Indonesia Periode 2011-2015. Jurnal Akuntansi Fakultas Ekonomi Universitas Pakuan.

Al Najjar, Basil, 2012, Dividens behavior and smoothing new evidence from Jordanian panel data," University of the West of England, Vol 1, hal $1-27$

Ashari, M. H. and Sampurno, R. D. 2017. Pengaruh Leverage Keuangan Terhadap Profitabilitas Pada Perusahaan Pariwisata Yang Terdaftar Di Bursa Efek Indonesia Periode 2011-2015, 6 (2002).

Astuti, Pudji. 2017. The Influences of Fundamental Factors and Systematic Risk to Stock Prices on Companies Listed in the Indonesian Stock Exchange. European Research Studies Journal. Vol. 20. Pp 230-240.
Brigham, Eugene F, and Ehrhardt, M.C. 2015. Financial Management: Theory and Practice, 11 th Edition, Thomson, South Western

Brigham, Eugene dan Houston, J.F. 2015. Fundamentals of Financial Management (terjemahan). Jakarta: Salemba Empat.

Fadli, Achmad Agus Yasin. 2013. Analisis Pengaruh Debt To Equity Ratio, Return On Asset, Dan Current Ratio Terhadap Dividend Payout Ratio Dan Dampaknya Pada Nilai Perusahaan (Studi pada Industri Manufaktur di Bursa Efek Indonesia Periode Tahun 2010-2012). Jurnal Bisnis STRATEGI Vol. 22 No. 2

Fahmi, Irham. 2015. Pengantar Manajemen Keuangan Teori dan Soal Jawab.Bandung: Alfabeta

Harahap, Sofyan Syafri. 2014. Analisis Kritis atas Laporan Keuangan. Edisi 1-10. Jakarta: Rajawali Pers

Hargiansyah, Rifqi Faisal. 2015. Pengaruh Ukuran Perusahaan, Leverage, dan Profitabilitas terhadap Nilai Perusahaan (Studi Empiris pada Perusahaan Manufaktur yang terdaftar di Bursa Efek Indonesia). Artikel ilmiah Mahasiswa.

Hasania, et al. 2016. Pengaruh Current Ratio, Ukuran Perusahaan Struktur Modal, Dan Roe Terhadap Nilai Perusahaan Farmasi Yang Terdaftar Di Bursa Efek Indonesia Periode 2011 - 2014. Jurnal Berkala Ilmiah Efisiensi Volume 16 No. 03

Hasibuan, V. and Ar, M. D. 2016. Pengaruh Leverage Dan Profitabilitas Terhadap Nilai Perusahaan (Studi pada Perusahaan 
Property dan Real Estate yang Terdaftar di Bursa Efek Indonesia Periode Tahun 2012-2015), 39 (1)

Hery. 2016. Financial Ratio For Business. Jakarta : Grasindo

Husnan, Suad dan Enny Pudjiastuti. 2012 Dasar-Dasar Manajemen

Keuangan. Edisi Ketujuh. Yogyakarta: UPP STIM YKPN

Kasmir. 2015. Analisis Laporan Keuangan Ed. 1. Jakarta : Rajawali Pers.

Marusya, Pontororing, and Mariam Magantar. 2016. Pengaruh Struktur Modal terhadap Profitabilitas pada Perusahaan Tobacco Manufakturers yang Terdaftar di Bursa Efek Indonesia (BEI) Periode 2008-2015. Jurnal Berkala Ilmiah Efisiensi, 16(3), hal. 484-492.

Mery, K. N. 2017. The Effect of Liquidity, Leverage and Profitability of the Corporate's Value with Dividend Policy as Moderation on Mining Companies at The Indonesia Stock Exchange Year 2011-2014', Jurnal Online Mahasiswa (JOM) Bidang Akuntansi, 4(1)

Noerirawan, 2012. Pengaruh Faktor Internal dan Eksternal Perusahaan Terhadap Nilai Perusahaan. Jurnal Akuntansi Vol.1 No. 2, hal. 4

Nurminda et al. 2017. Pengaruh Profitabilitas, Leverage, dan Ukuran perusahaan terhadap Nilai Perusahaan. E-Procceding of management. Vol. 4 No. 1

Pratiwi, Nadya dan Rahayu, Sri. 2015. Pengaruh Profitabilitas, Leverage, Good Corporate Governance, dan Ukuran Perusahaan terhadap Nilai
Perusahaan. (Studi kasus pada perusahaan yang terdaftar pada bursa efek indonesia yang memiliki skor corporate governance perception index (CGPI) selama periode 20102013. Artikel Ilmiah Mahasiswa.

Putra, A. N. D. A. and Lestari, P. V. 2016. Pengaruh Kebijakan Dividen, Likuiditas, Profitabilitas Dan Ukuran Perusahaan Terhadap Nilai Perusaan, E-Jurnal Manajemen Unud, 5(7) doi: 10.1007/BF01637379.

Putri, Zahroh dan Endang. 2016. Pengaruh Rasio Likuiditas Dan Rasio Profitabilitas Terhadap Nilai Perusahaan (Studi pada Perusahaan Sektor Industri Barang Konsumsi yang Terdaftar di BEI Tahun 20122014). Jurnal Administrasi Bisnis (JAB) Vol.38 No.2

Ramadhani, Ridho, Akhmadi dan Kuswantoro. Pengaruh Leverage Dan Profitabilitas Terhadap Nilai Perusahaan Dengan Kebijakan Dividen Sebagai Variabel Intervening (Studi Kasus pada Perusahaan Manufaktur yang Terdaftar di Bursa Efek Indonesia Periode 2012-2016). Tesis. Universitas Sultan Ageng Tirtayasa.

Rumondor, R., Mangantar, M. and Sumarauw, J. S. B. 2015. Pengaruh Struktur Modal, Ukuran Perusahaan dan Risiko Perusahaan terhadap Nilai Perusahaan pada Sub Sektor Plastik dan Pengemasan di BEI', Jurnal EMBA, 3(3).

Sambora, M. N. 2014. Pengaruh Leverage Dan Profitabilitas Terhadap Nilai Perusahaan (Studi pada Perusahaan 
Food and Beverages yang terdaftar di BEI', 8(1).

Sartono, Agus. 2015. Manajemen Keuangan Teori dan Aplikasi Edisi 4. Yogyakarta : BPFE

Sekaran, Uma.2015. Research Method For Business: Metodologi Penelitian Untuk Bisnis. Buku 2 edisi 4. Jakarta: Salemba.

Setyabudi. 2018. Pengaruh Struktur Modal Terhadap Nilai Perusahaan Pada Perusahaan Manufaktur Yang Terdaftar Pada Bursa Efek Indonesia. Artikel Ilmiah Universitas Muhammadiyah Surakarta

Silvia dan Sari. 2018. Pengaruh Rasio Likuiditas Terhadap Profitabilitas pada PT. Mustika Ratu,Tbk. Seminar Nasional Teknologi dan Bisnis 2018 IIB DARMAJAYA

Sudana, I Made. 2012. Manajemen Keuangan Perusahaan Teori dan Praktik. Ed 2. Jakarta : Erlangga

Suffah, Roviqotus dan Riduwan, Akhmad dan. 2016. Pengaruh Profitabilitas, Leverage, Ukuran perusahaan dan Kebijakan dividen pada Nilai perusahaan. Jurnal ilmu dan riset akuntansi. Vol.5, No.2

Sukoco, Heri. 2013. AnalisisPengaruh Debt To Equity Ratio, Profitabilitas, Firm Size, Dan Likuiditas TerhadapNilai Perusahaan Melalui Mediasi Dividend Payout Ratio (Studi Pada Industri Manufaktur di Bursa Efek Indonesia Periode Tahun 2009-2011). Jurnal Bisnis Strategi, Vol. 22 No. 2.
Susanti, Rika. 2010. Analisis factor-faktor Yang Berpengaruh Terhadap Nilai Perusahaan. Fakultas Ekonomi, Universitas Diponegoro, Semarang: Tidak Dipublikasikan.

Syamsuddin, Lukman. 2013. Manajemen Keuangan Perusahaan : Konsep Aplikasi dalam : Perencanaan, Pengawasan, dan Pengambilan Keputusan. Jakarta : Rajawali Pers.

Wijaya, I. B. N. P. and Purnawati, N. K. 2014. Pengaruh Likuiditas dan Kepemilikan Institusional Terhadap Nilai Perusahaan Dimoderasi Oleh Kebijakan Dividen', Jurnal Universitas Udayana Bali, 3(2) doi: 10.1007/s10208-013-9180-x. 